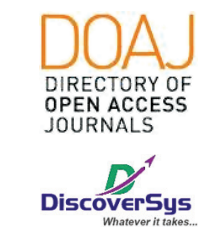

Published by DiscoverSys

\section{Gambaran biaya rawat inap pengobatan pneumonia pada pasien anak di RSUP Sanglah tahun 2018}

\author{
Anak Agung Ngurah Yamananda, ${ }^{1 *}$ Wayan Citra Wulan Sucipta Putri, ${ }^{2}$ \\ Putu Cintya Denny Yuliyatni ${ }^{3}$
}

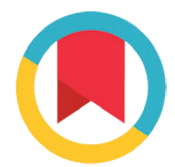

CrossMark

\title{
ABSTRACT
}

Introduction: Pneumonia is the leading cause of death on children in Indonesia with a percentage reaching $21 \%$, especially in infants aged less than 2 months. In the world, this disease is the number one killer of children where more than two million children have died from it, or causes one in five under-five deaths worldwide every year. High pneumonia morbidity and mortality rates are closely related to the quality of services, and the quality of resources in a health facility, up to the cost of treatment.

Method: This research is an observational research with descriptive research design, and uses crossectional data collection methods (cross section). This study aims to determine the description of pneumonia treatment consisting of direct medical costs, direct non-medical costs, and indirect costs of the average cost therapy for pneumonia in pediatric patients at the Sanglah Hospital inpatient care in 2018.

Result: Data were obtained from 21 samples of children with pneumonia. The average direct medical cost of patients was Rp. 3,838,270, the average direct non-medical cost is Rp. 1,443,076, and the average indirect cost is Rp. 941.905.

Conclusion: The average direct medical cost of a patient is Rp. 3,838,270, room costs are the largest component, $26.9 \%$ of the average total medical costs. The average direct non-medical cost of patients is Rp. 1,443,076, consumption costs are the largest component of non-medical costs, $51.3 \%$ of the average total non-medical costs. Average patient indirect costs are Rp. 941.905, maternal productivity costs are the largest indirect cost component, $67.8 \%$ of the average total indirect costs.

Keywords: pneumonia, cost analysis

Cite This Article: Yamananda, A.A.N., Putri, W.C.W.S., Yuliyatni, P.C.D. 2019. Gambaran biaya rawat inap pengobatan pneumonia pada pasien anak di RSUP Sanglah tahun 2018. Intisari Sains Medis 10(3): 785-790. D0I: 10.15562/ism.v10i3.455

\section{ABSTRAK}

Latar Belakang: Pneumonia merupakan penyebab utama kematian pada balita di Indonesia dengan persentase mencapai $21 \%$, terutama pada bayi yang berumur kurang dari 2 bulan. Di dunia, penyakit ini menjadi pembunuh nomor satu balita dimana lebih dari dua juta balita telah meninggal karenanya, atau penyebab satu dari lima kematian balita di seluruh dunia setiap tahunnya. Angka kesakitan dan kematian pneumonia yang tinggi sangat terkait dengan mutu layanan dan kualitas sumber daya di suatu fasilitas kesehatan, sampai dengan pembiayaan terapinya.

Metode: Penelitian ini merupakan jenis penelitian observasional

'Program Studi Pendidikan Dokter, Fakultas Kedokteran Universitas Udayana

${ }^{2}$ Departemen IImu Kedokteran Komunitas/llmu Kedokteran Pencegahan, Fakultas Kedokteran Universitas Udayana

*Korespondensi:

A.A Ngurah Yamananda, Program Studi Pendidikan Dokter, Fakultas Kedokteran Universitas Udayana p.yamananda.24@gmail.com

Diterima: 20-03-2019

Disetujui: 21-11-2019

Diterbitkan: 01-12-2019 dengan rancangan penelitian deskriptif, dan menggunakan metode pengambilan data crossectional (potong lintang) untuk mengetahui gambaran pengobatan pneumonia yang terdiri dari biaya medis langsung, biaya non medis langsung, dan biaya tidak langsung dari
Kata kunci: pneumonia, analisis biaya

\section{PENDAHULUAN}

Pneumonia merupakan penyakit infeksi yang dapat disebabkan oleh bakteri, virus, serta mikoplasma. ${ }^{1}$ Oleh karena itu, pengobatan pneumonia rata-rata biaya terapi pneumonia pada pasien anak di instalasi rawat inap RSUP Sanglah pada tahun 2018.

Hasil: Data dari 21 sampel pasien pneumonia anak, rerata biaya medis langsung pasien adalah sejumlah Rp. 3.838.270, rerata biaya non medis langsung adalah sejumlah $\mathrm{Rp}$. 1.443.076, dan reratabiaya tidak langsung adalah sejumlah Rp. 941.905.

Simpulan: Rerata biaya medis langsung pasien adalah sejumlah Rp. 3.838.270, biaya kamar adalah komponen terbesar, $26.9 \%$ dari rerata total biaya medis. Rerata biaya non medis langsung pasien adalah Rp. 1.443.076, biaya konsumsi adalah komponen biaya non medis terbesar, $51.3 \%$ dari rerata total biaya non medis. Rerata biaya tidak langsung pasien adalah Rp. 941.905, biaya produktifitas ibu adalah komponen biaya tidak langsung terbesar, $67.8 \%$ dari rerata total biaya tidak langsung.

Cite Pasal Ini: Yamananda, A.A.N., Putri, W.C.W.S., Yuliyatni, P.C.D. 2019. Gambaran biaya rawat inap pengobatan pneumonia pada pasien anak di RSUP Sanglah tahun 2018. Intisari Sains Medis 10(3): 785-790. D0I: 10.15562/ism.v10i3.455

harus menggunakan antimikroba yang berfungsi untuk mematikan atau menghambat mikroorganisme tersebut, sehingga toksisitasnya menjadi 
lebih kecil. ${ }^{2}$ Pneumonia menyerang saluran pernafasan bagian bawah yang menyebabkan masalah di berbagai negara di dunia, mengingat angka morbiditas dan mortalitas yang telah ditimbulkannya tergolong sangat tinggi. Di dunia, penyakit ini menjadi pembunuh nomor satu balita, dimana lebih dari 2 juta balita meninggal karenanya, atau menjadi penyebab kematian satu dari lima balita di seluruh dunia setiap tahunnya. ${ }^{3}$ Data dari World Health Organization atau WHO, juga menunjukkan bahwa pneumonia menjadi penyebab kematian sekitar 1,2 juta anak setiap tahunnya, sehingga dapat dikatakan, setiap jam ada 230 anak di dunia yang meninggal karena pneumonia. ${ }^{4}$

Di sebagian besar negara berkembang termasuk Indonesia, pneumonia merupakan penyebab kematian terbesar pada balita, dengan persentase angka kematian diperkirakan mencapai angka $21 \%$, dan disebutkan bahwa pada tahun 2006, Indonesia adalah negara dengan insiden pneumonia ke-6 terbanyak di dunia. ${ }^{3}$ Prediksi kasus baru dan insiden pneumonia balita paling tinggi terkonsentrasi pada enam negara, yang mencakup 44\% populasi balita di seluruh dunia. Keenam negara tersebut adalah India sebanyak 43 juta kasus, disusul oleh China 21 juta kasus, Pakistan 10 juta kasus, Bangladesh, Nigeria, dan Indonesia masing-masing sebanyak enam juta kasus per tahun. ${ }^{5}$ Bali merupakan provinsi nomor dua dengan kejadian pneumonia tertinggi di Indonesia pada tahun 2007, yaitu sebesar $11,1 \%,{ }^{6}$ sedangkan Denpasar merupakan kota dengan kasus pneumonia tertinggi nomor empat di Provinsi Bali yang mencapai 18,73\%.7

Tidak hanya di Negara Indonesia dan negara berkembang lainnya, pneumonia juga masih menjadi masalah pada negara maju, seperti Amerika Serikat. Pada tahun 2006, pneumonia termasuk ke dalam 8 penyakit utama yang menyebabkan kematian di Amerika Serikat. Tingkat kematian pada pasien rawat jalan kurang dari 5\%, sedangkan pada pasien rawat inap rata-rata $12 \%$, dan sebanyak $40 \%$ pasien membutuhkan perawatan di Intensive Care Unit /ICU. ${ }^{8}$ Dalam suatu penelitian di Amerika Serikat, biaya perawatan pneumonia pada anak adalah $\$ 1.464$ dengan biaya rata-rata untuk pasien yang membutuhkan rawat inap adalah \$ 12.000 per-episode. ${ }^{9}$ Analisis biaya pengobatan dan perawatan pneumonia yang memerlukan rawat inap telah tercatat cukup mahal, terutama apabila disertai dengan adanya komorbiditas atau penyakit lain yang menyertai. ${ }^{10}$

\section{METODE}

Penelitian ini merupakan jenis penelitian deskriptif observasional, dan menggunakan metode pengambilan data crossectional (potong lintang). Penelitian ini bertujuan untuk mengetahui gambaran pengobatan pneumonia yang terdiri dari biaya medis langsung, biaya non medis langsung, dan biaya tidak langsung dari rata-rata biaya terapi pneumonia pada pasien anak di instalasi rawat inap RSUP Sanglah pada tahun 2018.

Sampel adalah pasien pneumonia anak yang telah memenuhi kriteria inklusi. Kriteria inklusi adalah pasien anak yang terdiagnosis klinis pneumonia, baik laki-laki maupun perempuan, dengan data rekam medis dan kuitansi lengkap di instalasi rawat inap RSUP Sanglah tahun 2018. Kriteria ekslusi adalah pasien dengan data rekam medis atau kuitansi yang tidak lengkap, dan pasien pneumonia yang keluar rumah sakit dengan status pulang paksa atau meninggal. 21 sampel diperoleh dengan menggunakan teknik consecutive sampling.

Penelitian ini menggunakan data primer dan data sekunder. Data primer diambil dengan lembar kuisioner melalui wawancara langsung, sedangkan data sekunder diperoleh dari data rekam medis serta billing BPJS instalasi rawat inap anak RSUP Sanglah. Analisis data dilakukan dengan program statistik komputer secara univariat dan bivariat untuk mengetahui kecenderungan perbedaan biaya, yang meliputi karakteristik demografis pasien, jenis pneumonia, dan length of stay.

\section{HASIL}

Dari 21 sampel penelitian, distribusi frekuensi berdasarkan karakteristik demografis disajikan pada table 1. Karakteristik demografis terdiri dari usia pasien, jenis kelamin, pekerjaan orang tua, pendapatan orang tua, suku bangsa, dan area asal tempat tinggal pasien. Informasi didapat dari kuisoner hasil wawancara langsung orang tua pasien oleh peneliti. Kategori usia pasien dikelompokkan berdasarkan pembagian usia anak standar (Kail, Robert V., 2011). Kategori pendapatan orang tua pasien dikelompokkan menggunakan cut-off point UMK Kota Denpasar Tahun 2018, yaitu sebesar Rp. 2.363.000. Pada penelitian ini kategori area tempat tinggal pasien dikelompokkan jarak jauh dekatnya oleh peneliti, berdasarkan distribusi jarak setiap kabupaten di Bali menuju Kota Denpasar pada Badan Pusat Statistik Provinsi Bali Tahun 2018. Kategori jarak dekat $(<30 \mathrm{Km})$, meliputi Kota Denpasar, Kabupaten Badung, Tabanan, dan Gianyar, sedangkan kategori jarak jauh $(>30 \mathrm{Km})$, meliputi Kabupaten Bangli, Karangasem, dan Klungkung.

Dari kategori usia pasien $>1-12$ bulan (infant), usia terbanyak adalah 2 bulan sebanyak $28.6 \%$ dari seluruh sampel, dengan rerata usia 11,6 bulan. Persebaran jenis kelamin pasien dapat terbilang hampir sama, 11 orang laki-laki dan 10 orang 
perempuan. Mayoritas pekerjaan orang tua pasien adalah sebagai wiraswasta, sebanyak $61.9 \%$. Rentangan pendapatan orang tua pasien pada seluruh sampel sejumlah Rp. 500.000 Rp. 12.000.000, dengan rerata Rp. 3.409.524 dan nilai tengah Rp. 2.200.000. Hampir seluruh sampel merupakan suku bangsa Bali, hanya ada 1 sampel yang memiliki suku bangsa Jawa. Asal tempat tinggal pasien beragam hampir dari seluruh kabupaten yang ada di Bali, dengan frekuensi terbanyak adalah Kota Denpasar (kategori jarak dekat) sebanyak 33.3\%.

Jenis pneumonia pada penelitian ini, terbagi menjadi 2 kelompok, yaitu pneumonia berat dan hospital acquired pneumonia (HAP). Informasi sampel didapat dari data sekunder rekam medis setiap pasien. Setelah pengumpulan data, ditemukan bahwa frekuensi jenis pneumonia berat lebih

\section{Tabel 1 Distribusi Karakteristik Demografis}

\begin{tabular}{|c|c|c|c|c|}
\hline Karakteristik Demografis & Mean & Median & $\begin{array}{l}\text { Frequensi } \\
\text { (n) }\end{array}$ & $\begin{array}{c}\text { Persentase } \\
(\%)\end{array}$ \\
\hline Usia Pasien (bulan) & 11,6 & 3,0 & & \\
\hline $0-1$ (newborn) & & & 1 & 4.8 \\
\hline$>1-12$ (infant) & & & 16 & 76.1 \\
\hline$>12-36($ toddler $)$ & & & 2 & 9.5 \\
\hline$>36-72$ (preschooler) & & & 1 & 4.8 \\
\hline$>72$ (schooler $)$ & & & 1 & 4.8 \\
\hline \multicolumn{5}{|l|}{ Jenis Kelamin } \\
\hline Laki - laki & & & 11 & 52.4 \\
\hline Perempuan & & & 10 & 47.6 \\
\hline \multicolumn{5}{|l|}{ Pekerjaan Orang Tua } \\
\hline Pegawai Negeri Sipil & & & 2 & 9.6 \\
\hline Pegawai Swasta & & & 4 & 19.0 \\
\hline Wiraswasta & & & 13 & 31.9 \\
\hline Satpam & & & 1 & 4.8 \\
\hline Petani & & & 1 & 4.8 \\
\hline Pendapatan Orang Tua (rupiah) & 3.409 .524 & 2.200 .000 & & \\
\hline Dibawah UMK & & & 11 & 52.4 \\
\hline Diatas UMK & & & 10 & 47.6 \\
\hline \multicolumn{5}{|l|}{ Suku Bangsa } \\
\hline Bali & & & 20 & 95.2 \\
\hline Jawa & & & 1 & 4.8 \\
\hline \multicolumn{5}{|l|}{ Area Tempat Tinggal } \\
\hline Jarak Dekat (<30 Km) & & & 12 & 57.1 \\
\hline Jarak Jauh (>30 Km) & & & 9 & 42.9 \\
\hline
\end{tabular}

Tabel 2 Distribusi Biaya Medis Langsung

\begin{tabular}{lcccc}
\hline & & & \multicolumn{2}{c}{ Range } \\
\cline { 4 - 5 } Komponen Biaya (Rupiah) & Mean & Median & Minimum & Maximum \\
\hline Biaya Obat & 956.679 & 621.800 & 9390 & 6.412 .962 \\
Biaya Penunjang & 866.696 & 871.000 & 0 & 2.208 .500 \\
Biaya Tindakan & 146.691 & 0 & 0 & 648.000 \\
Biaya Kamar & 1.032 .119 & 929.250 & 0 & 5.200 .000 \\
Biaya Administrasi & 50.619 & 20.000 & 0 & 354.000 \\
Biaya Medis Lainnya & 785.464 & 657.500 & 0 & 3.402 .500 \\
Total Biaya Medis & 3.838 .270 & 3.379 .912 & 39.390 & 14.036 .000 \\
\hline
\end{tabular}


Tabel 3 Distribusi Biaya Non Medis Langsung

\begin{tabular}{lcccc}
\hline & & & \multicolumn{2}{c}{ Range } \\
\cline { 4 - 5 } Komponen Biaya (Rupiah) & Mean & Median & Minimum & Maximum \\
\hline Biaya Konsumsi & 740.676 & 464.000 & 147.000 & 2.565 .000 \\
Biaya Transportasi & 311.471 & 178.900 & 0 & 1.500 .000 \\
Biaya Keagamaan & 79.600 & 55.000 & 0 & 240.000 \\
Biaya MCK & 265.238 & 185.000 & 15.000 & 968.500 \\
Biaya Non Medis Lainnya & 46.095 & 0 & 0 & 303.000 \\
Total Biaya Non Medis & 1.443 .076 & 1.074 .500 & 342.000 & 3.880 .000 \\
\hline
\end{tabular}

Tabel 4 Distribusi Biaya Tidak Langsung

\begin{tabular}{lcccc}
\hline & & & \multicolumn{2}{c}{ Range } \\
\cline { 4 - 5 } Komponen Biaya (Rupiah) & Mean & Median & Minimum & Maximum \\
\hline Biaya Ayah & 302.857 & 0 & 0 & 3.000 .000 \\
Biaya Ibu & 639.048 & 0 & 0 & 4.000 .000 \\
Total Biaya Tidak Langsung & 941.905 & 300.000 & 0 & 7.000 .000 \\
\hline
\end{tabular}

banyak dibandingkan HAP, dengan perbandingan $2: 1$. Dari total 21 sampel sebanyak $66.7 \%$ sampel terdiagnosis pneumonia berat, dan $33.3 \%$ sampel terdiagnosis HAP.

Length of stay merupakan episode waktu yang dijalani pasien dari hari pertama rawat inap sampai pulang kembali, atau dinyatakan telah sembuh. Length of Stay menunjukkan berapa lama pasien dirawat inap, dalam hitungan hari. Setelah pengumpulan data didapatkan rentangan length of stay pasien adalah dari 4 - 13 hari, dengan rerata 7.5 hari, dan median 8 hari. Frekuensi terbanyak yaitu selama 5 hari, sebanyak $33.3 \%$ dari seluruh sampel.

Biaya medis langsung merupakan total dari beberapa komponen biaya yaitu biaya obat, biaya penunjang, biaya tindakan, biaya kamar, biaya admisnistrasi, dan biaya medis lainnya. Distribusi biaya medis langsung dapat dilihat pada tabel 2 . komponen biaya medis langsung terbanyak adalah biaya kamar, yaitu sebanyak $26.9 \%$ dari rerata total biaya medis, yang diikuti dengan biaya obat dan biaya penunjang.

Biaya non medis langsung merupakan total dari beberapa komponen biaya yaitu biaya konsumsi, biaya transportasi, biaya kegiatan kegamaan, biaya MCK, dan biaya non medis lainnya. Distribusi biaya non medis langsung dapat dilihat pada tabel 3. komponen biaya non medis langsung terbanyak adalah biaya konsumsi, sebanyak $51.3 \%$ dari rerata total biaya non medis, yang diikuti dengan biaya transportasi dan biaya MCK.

Biaya tidak langsung merupakan total biaya produktifitas caregiver pasien yang hilang selama pasien dirawat inap (jika ada). Caregiver umumnya adalah orang tua pasien, ayah dan juga ibu pasien. distribusi biaya tidak langsung disajikan pada tabel 4. komponen biaya tidak langsung dari biaya ibu lebih banyak dibandingkan dengan biaya ayah, yaitu $67.8 \%$ dari rerata total biaya tidak langsung. Terdapat 9 (42.9\%) sampel dari seluruh sampel yang total akumulasi biaya tidak langsungnya Rp. 0 , karena memang tidak ada biaya produktifitas caregiver pasien yang hilang selama pasien dirawat inap.

\section{DISKUSI}

Pada penelitian ini usia sampel berkisar dari rentangan diatas 28 hari/0 bulan (newborn), sampai dengan dibawah 7 tahun (schooler) yang diambil secara prospektif, hal ini sejalan dengan penelitian Sheila E.A.N. dkk (2017), yang pada sampel penelitiannya juga dimulai dari usia pasien diatas 28 hari, dan mengambil secara prospektif. ${ }^{11}$ Hanya saja sampel pada penelitian tersebut lebih banyak, yaitu 59 sampel pasien dengan diagnosis pneumonia, sedangkan pada penelitian ini hanya mendapatkan 21 sampel, yang dikarenakan oleh periode waktu penelitian yang terbatas.

Dari 21 sampel, didapatkan lebih banyak pasien dengan jenis kelamin laki-laki (52.4\%), dibandingkan perempuan (47.6\%), Hal ini serupa dengan penelitian lain Sheila E.A.N. dkk (2017), yang pada sampelnya juga lebih banyak persentase pasien dengan jenis kelamin laki-laki (57.6\%), dibandingkan dengan perempuan (42.4\%). ${ }^{11}$

Asal area tempat tinggal pasien pada penelitin ini beragam, hampir dari seluruh kabupaten yang ada di Bali, walaupun hanya mengambil dari 1 rumah sakit, yaitu RSUP Sanglah Denpasar. Hal tersebut 
tidak sesuai dengan penelitian Sheila E.A.N. dkk (2017), yang sampelnya berasal dari 2 rumah sakit yang berbeda. ${ }^{11}$ Perbedaan disebabkan oleh karena peneliti hanya melakukan penelitian pada rumah sakit umum tipe A saja, dan di Provinsi Bali rumah sakit umum tipe A terbatas yaitu hanya RSUP Sanglah Denpasar.

Pada penelitian ini didapatkan 2 jenis pneumonia, yaitu pneumonia berat dan hospital acquired pneumonia (HAP), dengan persentase pneumonia berat $66.7 \%$, dan HAP $33.3 \%$ dari seluruh sampel. Hal ini tidak sesuai dengan penelitian Sheila E.A.N. dkk (2017), yang pada penelitiannya mendapatkan 2 jenis pneumonia yaitu pneumonia berat (88.1\%) dan pneumonia sangat berat (11.9\%). ${ }^{11}$ Hal ini disebabkan karena pada penelitian ini peneliti tidak mencari kasus pneumonia di ruang ICU, sehingga tidak ada ditemukannya diagnosis pneumonia sangat berat.

Rentangan length of stay pada penelitian ini adalah $4-13$ hari, dengan rerata 7.5 hari. Hal ini kurang sesuai dengan penelitian lain Nuraini (2012), yang pada penelitiannya mendapatkan rerata rentangan length of stay pasien pneumonia 4 6.6 hari. ${ }^{12}$ Perbedaan hasil dapat disebabkan karena perbedaan jenis atau tingkat keparahan pneumonia, kualitas pelayanan medis masing-masing rumah sakit, komplikasi lain atau penyakit penyerta setiap pasien.

Pada penelitian ini komponen biaya medis langsung terbesar adalah biaya kamar, yaitu sebanyak $26.9 \%$ dari rerata total biaya medis. Hal ini sejalan dengan penelitian Sheila E.A.N. dkk (2017), yang menampilkan dalam tabel bahwa komponen biaya medis terbesar adalah hospital service cost, sebesar $65.0 \%$ dari rerata total biaya medis. ${ }^{11}$ Tetapi tidak sejalan dengan penelitian Nuraini (2012), yang menyebutkan komponen biaya medis terbesar adalah biaya tindakan sebesar $44.1 \%{ }^{12}$ Perbedaan ini disebabkan karena pada penelitian N. Nuriaini (2012) banyak terdapat pasien pneumonia dengan penyakit penyerta, dan memerlukan tindakan lebih dari tenaga medis untuk menolong, sehingga biaya tindakan bertambah.

\section{KETERBATASAN}

Pada metode sampling, sampel minimal yang harus didapat adalah sebanyak 52 sampel, tetapi kenyataan di lapangan selama periode waktu yang telah ditentukan, hanya mendapatkan 21 sampel. Hal ini disebabkan karena regulasi berobat pasien yang sudah berubah, yaitu lebih banyak menuju ke RSUD terlebih dahulu, sehingga menyebabkan berkurangnya jumlah pasien pneumonia yang masuk di RSUP Sanglah.

Selain itu kelemahan penelitian ini adalah peneliti tidak meneliti kasus pneumonia di ruang ICU, karena masalah ijin penelitian, sehingga tidak mendapatkan kasus pneumonia sangat berat. Kelemahan lain adalah adanya bias informasi dari orang tua pasien yang mengisi kuisioner wawancara, beberapa responden hanya mengisi seadanya dan sebatas yang mereka ingat saja, karena sedang dalam suasana berduka menunggu anaknya sakit dan tidak ingin diganggu.

\section{SIMPULAN}

Pasien dengan jenis pneumonia berat lebih banyak dibandingkan HAP (hospital acquired pneumonia), dengan perbandingan 2:1. Rentangan length of stay pasien adalah dari 4 - 13 hari, dengan rerata 7.5 hari. Frekuensi terbanyak yaitu selama 5 hari (33.3\%). Rerata biaya medis langsung pasien adalah sejumlah Rp. 3.838.270, dengan komponen biaya medis terbesar adalah biaya kamar, $26.9 \%$ dari rerata total biaya medis. Rerata biaya non medis langsung pasien adalah sejumlah Rp. 1.443.076, dengan komponen biaya non medis terbesar adalah biaya konsumsi, $51.3 \%$ dari rerata total biaya non medis. Rerata biaya tidak langsung pasien adalah sejumlah Rp. 941.905, dengan komponen biaya tidak langsung terbesar adalah biaya produktifitas ibu, $67.8 \%$ dari rerata total biaya tidak langsung.

\section{KONFLIK KEPENTINGAN}

Penulis menyatakan tidak terdapat suatu konflik kepentingan terhadap publikasi dari artikel ini.

\section{PENDANAAN}

Penelitian ini tidak mendapatkan suatu pendanaan yang diberikan oleh pemerintah ataupun lembaga swasta lainnya.

\section{KONTRIBUSI PENULIS}

Konsep penelitian: Ngurah Yamananda, Wayan Citra Wulan Sucipta, Putu Cintya Denny Yuliyantni. Pengumpulan data, input data dan pengolahan data: Ngurah Yamananda. Penyusunan naskah Penelitian: Ngurah Yamananda.

\section{ETHICAL CLEARANCE NUMBER}

487/UN.14.2/KEP/2018. 


\section{DAFTAR PUSTAKA}

1. Nandika WP., Siadi PP. Hubungan status gizi terhadap angka kejadian community-acquired pneumonia (CAP) pada balita di RSUP Sanglah Denpasar. Intisari Sains Medis. 2018. 9(3). DOI: 10.15562/ism.v9i3.178

2. Price SA., Wilson L. Patofisiologi Konsep Klinis ProsesProses Penyakit Edisi 6 Volume 2, Egc Kedokteran, Jakarta. 2006.

3. UNICEF/WHO. Pneumonia: the forgotten killer of children. Geneva: The United Nations Children's Fund/World Health Organization. 2006.

4. World Health Organization. Pneumonia. Fact sheet $\mathrm{N}^{\circ} 331$ [cited 2013 Nov 13]. 2013.

5. Rudan, Igor, dkk. Epidemiology and etiology of childhood pneumonia. Bulletin of the World Health Organization. 2008. 86: 408-416.

6. Kementerian Kesehatan Republik Indonesia. Laporan riset kesehatan dasar. 2007. Jakarta: Badan Penelitian dan Pengembangan Kesehatan, Kementerian Kesehatan Republik Indonesia. 2007.

7. Dinas Kesehatan Kota Denpasar. Profil Kesehatan Kota Denpasar Tahun 2013. 2013.

8. Alldredge BK., Corelli RL., Ernst ME. Koda-Kimble and Young's Applied Therapeutics: The Clinical Use of Drugs, Lippincott Williams \& Wilkins. 2012.
9. Bradley JS., Byington CL., Shah SS., Alverson B., Carter ER., Harrison C., dkk. Executive Summary: The Management of Community-Acquired Pneumonia in Infants and Children Older Than 3 Months of Age: Clinical Practice Guidelines by the Pediatric Infectious Diseases Society and the Infectious Diseases Society of America. Clinical Infectious Diseases 2011. 53: 617-630.

10. Bauer TT., Welte T., Ernen C., Schlosser BM., Waschke IT., Zecuw J., Werninghaus GS. 2005. Cost Analysis of Community Acquired 17 Pneumonia from the Hospital Perspective. Chest. 2005. 128. 2238- 2246.

11. Sheila EAN., Ruth M, Maria ADSV, dkk. Hospitalization costs of severe bacterial pneumonia in children: comparative analysis considering different costing methods. 2017.

12. Nuraini N. Gambaran Pengobatan dan Analisis Biaya Terapi Pneumonia pada Pasien Anak di Instalasi Rawat Inap RS "X" Tahun 2011, Fakultas Farmasi Univesitas Muhammadiyah Surakarta. 2012.

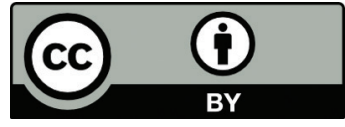

This work is licensed under a Creative Commons Attribution 